\title{
PERANAN INSTITUT PENYELIDIKAN PERUBATAN DALAM MENANGANI MASALAH SOSIOEKONOMI NEGERI-NEGERI MELAYU BERSEKUTU, 1896-1914
}

\author{
Sawi Linus Sungat \\ Sivachandralingam Sundara Raja
}

\begin{abstract}
This paper aims to analyze the roles played by the Medical Research Institute (Institute of Medical Research, IMR) in addressing health problems in the Federated Malay States (FMS) from 1896 to 1914 and how these efforts have solved the socio-economic problems faced by the British during the period. The extensive opening up of lands for commercial and mining activities in the FMS had led to the influx of large immigrant labourers among whom sickness and death rate was relatively high. This had, in turn, affected the production of cash crops and minerals (such as rubber and tin), prompting the British for more research to find solutions. The IMR found a solution for the problem with the discovery of new vaccines for treating various diseases that were prevalent among foreign workers. It was thus directly involved in solving the socio-economic problems faced by the FMS government. This article elaborates the rationale for the establishment of the institute; the extent to which it was successfull in tackling diseases particularly among immigrant labourers and how it contributed to the socio-economic development of the FMS.
\end{abstract}

\section{Tujuan Penubuhan Institut Penyelidikan Perubatan}

Institut Penyelidikan Perubatan atau Institute of Medical Research (IMR) didirikan di Kuala Lumpur pada tahun $1900^{1}$ di bawah kepimpinan Sir Frank Swettenham, Residen Jeneral Negeri-Negeri Melayu Bersekutu (NNMB). NNMB dipilih memandangkan berlakunya penularan serius dua jenis penyakit tropika ketika itu iaitu beri-beri dan malaria. Instituy ini juga diharap dapat menyaingi pusat penyelidikan perubatan kuasa lain di Timur Jauh. ${ }^{2}$ Kerjasama antara pentadbir tertinggi dan tenaga perubatan di NNMB juga berjaya merealisasikan penubuhan IMR. ${ }^{3}$ Frank Sweettenham dan Joseph Chamberlain merupakan pentadbir tertinggi yang berperanan penting, ${ }^{4}$ sementara tenaga perubatan pula merupakan Dr. Manson. ${ }^{5}$ Pada awal penubuhannya, institut ini dikenali sebagai Institut Patologi ${ }^{6}$ dan dibuka secara rasmi pada Februari 1901. Pada Ogos 1901, institut tersebut diberikan nama baru iaitu Institut Penyelidikan Perubatan atau Institute of Medical Research (IMR).

Tujuan penubuhan IMR adalah untuk menjalankan tugas penyelidikan secara saintifik bagi mencari penyelesaian, punca jangkitan, cara mengatasi dan mencari kaedah rawatan (ubat) atau penawar bagi mengubati penyakit-penyakit tropika seperti beri-beri dan malaria yang telah banyak mengorbankan nyawa pada masa tersebut. Ini kerana ketika itu penyakit beri-beri, cirit lendir dan darah (dysentery) dan malaria telah menyerang beriburibu mangsa, terutamanya buruh-buruh yang membina jalan raya dan kereta api, mereka yang membersihkan hutan belantara untuk tanaman getah dan mereka yang bekerja di lombong-lombong bijih timah. ${ }^{7}$ Institut ini juga menjadi makmal rujukan pusat dalam memberikan perkhidmatan mengenal penyakit dan nasihat kepada hospital dan klinik. Selain itu, IMR juga menjadi pusat latihan kepada juruteknologi makmal, doktor perubatan dan doktor haiwan. ${ }^{8}$ Institut ini muncul sebagai pusat penyelidikan bagi negara kolonial pada masa itu. 
Selain itu, tujuan British mendirikan IMR juga adalah untuk mempromosikan nilainilai kebudayaan Eropah. British ingin mematuhi Seminar Berlin tahun 1885 untuk mengendalikan aktiviti mempromosikan moral dan well-being material kepada penduduk asal dengan meneroka bidang perubatan tropika yang belum dikenal pasti. ${ }^{9}$

\section{IMR Sebelum Perang Dunia Pertama}

British mula bertapak di Negeri-negeri Melayu sejak akhir abad ke-19, dan penanaman modal dalam ekonomi telah memperlihatkan kemunculan bidang-bidang ekonomi baru seperti perusahaan getah dan kelapa sawit dalam bidang pertanian, dan bijih timah serta arang batu dalam aktiviti perlombongan. Perkembangan ini telah membawa kepada pengaliran masuk buruh-buruh asing terutamanya dari negara China dan India untuk membantu dalam sektor ekonomi kapitalis. British telah mengeksploitasi sumber ekonomi Negeri-negeri Melayu yang mengakibatkan perkembangan infrastruktur sosioekonomi seperti jalan kereta api, hospital, sekolah dan kemudahan asas lain. ${ }^{10}$ Buruh Cina dan India telah dibawa ke Tanah Melayu untuk memenuhi keperluan ini.11 Keadaan ini telah menyebabkan penyakit tropika seperti malaria telah merebak luas ekoran pembukaan hutan untuk tujuan perlombongan timah. Demam tropika sering menjangkiti buruh-buruh yang bekerja membuka jalan raya dan jalan kereta api untuk tujuan menghubungkan kesemua bandar di Tanah Melayu. ${ }^{12}$

\section{Peta 1: Sistem Perhubungan di Tanah Melayu Sebelum 1941}

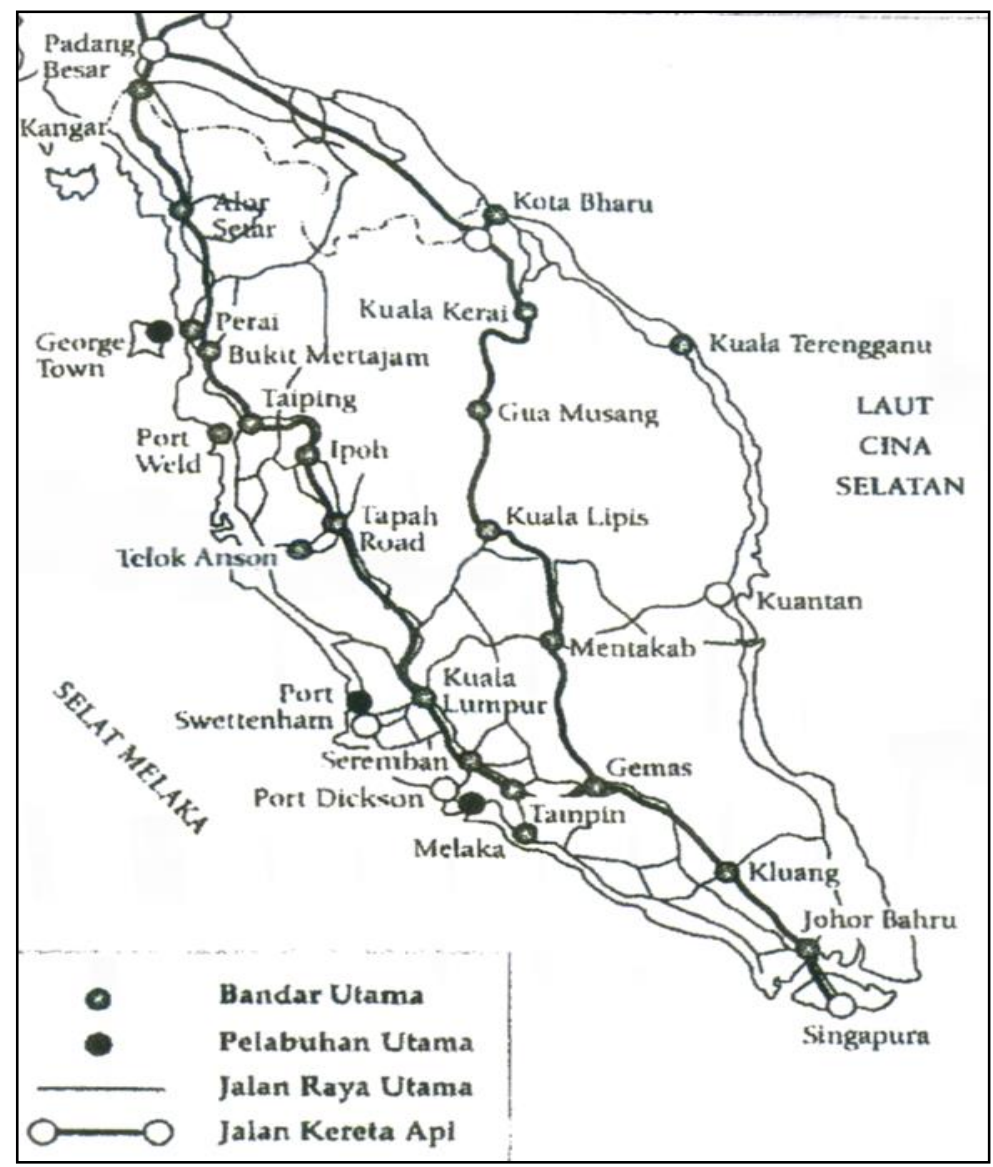

Sumber: Mohd. Isa Othman, Sejarah Malaysia: 1800-1963, Kuala Lumpur: Utusan Publication \& Distributors Sdn Bhd, 2002, hlm. 201.13 
Kebanyakan imigran mendapati sukar untuk menyesuaikan diri dengan cuaca dan keadaan persekitaran di Tanah Melayu. Mereka terdedah kepada pelbagai penyakit tropika seperti cacar, beri-beri, taun, cirit-birit dan lain-lain penyakit berjangkit. ${ }^{14}$ Menurut laporan surgen negeri, sebahagian besar imigran diserang wabak penyakit dengan cepat disebabkan kemasukan kaum asing secara besar-besaran dan pembukaan daerah baru secara mengejut untuk dijadikan kawasan penempatan, pembinaan jalan raya dan kegiatan penerokaan. ${ }^{15}$

Penyakit disenteri dan lain-lain penyakit tropika turut menyebabkan kematian dalam kalangan buruh perlombongan timah dan buruh perladangan. Keadaan ini semakin membimbangkan apabila sejumlah besar penduduk dan tenaga buruh mencatatkan peningkatan dari segi jumlah korban ${ }^{16}$ setiap hari. ${ }^{17}$ Wabak penyakit ini telah memberi tamparan hebat kepada pemerintah British kerana kadar kematian yang semakin meningkat dari setahun ke setahun. Memandangkan keadaan kesihatan telah mencapai satu peringkat yang membimbangkan dalam kalangan buruh, kerajaan British telah mengambil perhatian serius kerana buruh-buruh ini merupakan punca tenaga pembangunan ekonomi.

Pada tahun 1896, Frank Athelstane Swettenham, Residen Jeneral NNMB telah membuat kenyataan berikut, "... of the other institution that most nearly concern the public, ... I think, bear out the statement that the hospitals are very ably managed institutions; under the personal supervision of English surgeons". 18 Pernyataan tersebut jelas melambangkan kegigihan British dalam usaha membina dan memajukan perkhidmatan kesihatan di NNMB. Dalam hal ini, tumpuan akan diberikan kepada dua bentuk kemudahan kesihatan utama di NNMB dalam tempoh 1874-1914 iaitu hospital dan dispensari. ${ }^{19}$

Pada asalnya, cadangan penubuhan IMR dikemukakan oleh Residen Jeneral NNMB, Sir Frank Swettenham. Beliau mencadangkan sebuah institut penyelidikan diwujudkan bagi mengkaji dan menyelidik penyakit-penyakit di Tanah Melayu pada ketika itu seperti beriberi, malaria, tibi, taun dan sebagainya. Beliau berpendapat perlunya sebuah institut yang menjalankan kajian saintifik mengenai penyakit-penyakit ini dan mencadangkan agar institut ini diterajui oleh pakar perubatan yang terlatih dan berkemahiran tinggi. Cadangan Swettenham menjadi lebih kukuh dan berasas kerana ketika itu beberapa wabak penyakit telah melanda Tanah Melayu yang telah mengorbankan ramai penduduk.

Kesedaran mengenai bahaya penyakit tropika telah membuka mata pihak British untuk cuba mengatasi dan mengawalnya pada awal tahun 1900. Oleh sebab itu, melalui Surat Pekeliling No. 3135 bertarikh 10 Julai 1901, Institut Penyelidikan Perubatan atau Institute for Medical Research (IMR) telah ditubuhkan. ${ }^{20}$ Pada mulanya, institut ini dikenali sebagai The Kuala Lumpur Pathological Institute..$^{21}$ Kuala Lumpur telah dipilih sebagai lokasi untuk IMR kerana kedudukannya yang strategik dan terletak di tengah Tanah Melayu.

\section{Peranan IMR}

Peranan Institute for Medical Research (IMR) adalah untuk mempromosikan status kesihatan penduduk tempatan dan menerokai bidang perubatan tropika yang luas dan yang belum lagi diketahui umum. Pada permulaannya, peranan serta skop tanggungjawab IMR adalah luas dan pelbagai. Ianya merangkumi dari perkhidmatan diagnosis, penyiasatan dan rundingan kepada penyelidikan dan latihan.22 Sepanjang 10 tahun pertama penubuhannya, IMR menyumbang secara signifikan dalam penyelidikan terhadap punca dan rawatan dua masalah kesihatan yang penting pada masa itu, iaitu penyakit beri-beri dan malaria. IMR kemudiannya melibatkan diri dalam penyelidikan mengesan punca, penyebaran, rawatan serta pencegahan pelbagai penyakit tropika termasuk taun, cacar, kusta, batuk kering, tifoid, filariasis, denggi, tifus skrub dan kekurangan zat makanan. ${ }^{23}$

Sehingga tahun 1914, IMR diterajui oleh tiga orang pengarah iaitu Dr. Hamilton Wright $^{24}$ (1900-1903); Dr. C.W. Daniels ${ }^{25}$ (1903-1905) dan Dr. Henry Fraser ${ }^{26}$ (1906-1916). ${ }^{27}$ Penyelidikan beri-beri menjadi keutamaan mereka. Justeru, sumbangan IMR terhadap 
pengetahuan berkenaan beri-beri dan penyakit tropika yang lain amat bermakna. ${ }^{28}$ Pengkaji dan penyelidik di institut ini berpeluang untuk mendapatkan maklumat terperinci mengenai penyakit-penyakit tertentu yang hanya ditemui di kawasan tropika seperti penyakit beri-beri yang wujud hanya dalam keadaan tertentu, sementara penyakit malaria pula boleh ditemui dalam empat jenis yang berbeza. Pengarah IMR dipertanggungjawabkan untuk melakukan "...scientific and sustained research into the causes, and if possible, the means of preventing and curing such scourges as beri-beri...".29 Kakitangan lain seperti bakteriologis, ahli kimia dan patologis turut berperanan penting dalam penyelidikan beri-beri di IMR dalam tempoh 1900-1914.

Prestasi penyelidikan IMR boleh dinilai dengan jumlah penulisan saintifik yang diterbitkan tiap-tiap tahun, serta kadar dan luasnya hubungan dengan institut yang serupa menerusi pertukaran penerbitan dan pegawai. Semenjak penubuhan IMR, lebih 1,300 penulisan mengenai berbagai-bagai perkara saintifik telah diterbitkan. Penerbitan saintifik IMR dalam tempoh setiap sepuluh tahun adalah seperti berikut:

Jadual 1: Penerbitan Saintifik IMR, 1900-1949

\begin{tabular}{|c|c|}
\hline Tahun & Jumlah Penerbitan Saintifik \\
\hline $1900-1909$ & 14 \\
\hline $1910-1919$ & 11 \\
\hline $1920-1929$ & 93 \\
\hline $1930-1939$ & 83 \\
\hline $1940-1949$ & 71 \\
\hline
\end{tabular}

Sumber: 70 Tahun (1900-1970) Penyelidikan Perubatan di Pusat Penyelidikan Perubatan, Kuala Lumpur, 1971.

Penerbitan saintifik ini sangat penting sebagai sumber rujukan untuk para pengkaji dalam dan luar negara yang berminat untuk mengkaji penyakit tropika.

\section{Penyelidikan Terpilih IMR, 1896-1914}

Pada era ini, daripada sebuah jabatan persekutuan yang bebas, maka IMR telah menjadi satu cabang Jabatan Perubatan. Kerja rutin patologi untuk perkhidmatan perubatan perubatan yang ditawarkan meliputi kimia, toksikologi, patologi, bakteriologi dan perkhidmatan pertikaian undang-undang. Sumbangan IMR antara tahun 1896 hingga 1914 adalah ke arah penyelesaian masalah beri-beri, malaria dan disenteri. ${ }^{30}$ Perbincangan berikut akan memperincikan penyelidikan terpilih IMR dan bagaimana IMR menyumbang kepada kemampuan sosioekonomi NNMB.

\section{a. Kajian Penyakit Beri-beri}

Penyakit beri-beri mendapat perhatian khusus daripada kerajaan British kerana penyakit ini telah memberikan kesan buruk kepada ekonomi di Tanah Melayu. Penyakit ini telah menyebabkan kadar kematian di kalangan penduduk meningkat. Hal ini telah menyebabkan penyakit ini perlukan kajian.

Kajian penyakit beri-beri penting untuk mencari punca penyakit beri-beri dan kaedah rawatan yang berkesan untuk penyakit tersebut. Penyakit ini menjadi satu ancaman serius kepada penduduk Tanah Melayu. Oleh itu, penyelidikan saintifik perlu dibuat untuk menangani penularan penyakit tersebut. Seiring dengan perkembangan penyelidikan punca beri-beri banyak maklumat baru yang diketahui. ${ }^{31}$ Di Tanah Melayu, penularan beri-beri 
mula dikesan di Penjara Jenayah Singapura pada awal bulan Mei $1875^{32}$ dan Penjara Taiping, Perak dalam tahun 1879.33

Di antara ketiga-tiga orang pengarah Institut Penyelidikan Perubatan, Dr. Wright dan Dr. Daniels menumpukan usaha penyelidikan mereka untuk mengasingkan mikrob dari pesakit beri-beri bersandarkan kepada teori jangkitan, manakala Dr. Fraser pula lebih berminat untuk menguji teori keracunan beras yang dikemukakan oleh Dr. Braddon. ${ }^{34}$ Pada tahun 1907, Dr. Fraser, Dr. Stanton ${ }^{35}$ dan Dr. Braddon telah melakukan eksperimen menggunakan sekumpulan buruh Jawa untuk menguji hipotesis Dr. Braddon mengenai faktor etiologi beras Siam sebagai penyebab beri-beri. Penggunaan manusia untuk tujuan eksperimen ini telah mendapat reaksi pro dan kontra daripada Jawatankuasa Tabung Penyelidikan Penyakit-penyakit Tropika. ${ }^{36}$ Terdapat cadangan supaya digunakan haiwan anthropoid seperti monyet namun kesukaran mendapatkan haiwan berkenaan menyebab eksperimen yang berikutnya dijalankan dengan menggunakan ayam. ${ }^{37}$

Eksperimen yang dijalankan itu dikenali sebagai Eksperimen Durian Tipus. Kumpulan buruh tersebut dibahagikan kepada dua kelompok dan setiap satu diberikan sejenis beras yang berbeza iaitu beras Siam dan beras India. Hasil eksperimen menunjukkan beri-beri bukanlah penyakit berjangkit dan penyebab beri-beri didapati dalam beras Siam/beras putih. ${ }^{38}$ Dr. W. Fletcher ${ }^{39}$ (beliau memegang jawatan sebagai patologis IMR) turut menjalankan eksperimen yang sama di Kuala Lumpur dan memperoleh keputusan yang hampir sama. ${ }^{40}$

Selain itu, ujikaji kimia terhadap sampel beras Siam dan beras India turut dilakukan oleh ahli kimia IMR untuk memastikan perbezaan kandungan kimia yang terdapat dalam setiap satu sampel berkenaan. Kajian kimia yang berterusan terhadap sampel-sampel ini meyakinkan penyelidik IMR untuk membuat satu hipotesis iaitu kekurangan nutrien dalam beras adalah penyebab beri-beri dan bukan racun seperti mana diutarakan oleh Dr. Braddon. ${ }^{41}$

Pada awal tahun 1910, Dr. Fraser dan Dr. Stanton telah membuat satu kesimpulan tentang punca beri-beri iaitu akibat kekurangan nutrien dalam beras putih yang dimesin. Kesimpulan yang dicapai ini telah dikukuhkan dengan hasil eksperimen awal yang dilakukan oleh Dr. Fraser dan Dr. Stanton pada tahun 1907.42 Salinan laporan mereka yang bertajuk "On the Etiology of Beri-beri" telah diajukan kepada kerajaan India dan Burma, Setiausaha Kolonial Sri Lanka dan Setiausaha Kolonial Hong Kong, serta Jawatankuasa Penasihat Tabung Penyelidikan Penyakit-penyakit Tropika. ${ }^{43}$ Laporan tersebut juga telah dibentangkan oleh Dr. Fraser dalam kongres dwitahunan pertama Far Eastern Association of Tropical Medicine di Manila, Filipina pada bulan Mac $1910^{44}$ dan kongres kedua pada bulan Januari 1912.45

Sesungguhnya, penerimaan terhadap hasil eksperimen yang dijalankan oleh Dr. Fraser dan Dr. Stanton oleh khalayak perubatan di luar NNMB telah memberi satu sumbangan yang besar terhadap punca beri-beri yang telah diselidik sekian lama. ${ }^{46}$ Pada tahun 1913, satu resolusi muktamad tentang punca beri-beri dan penyelesaiannya telah dicapai. Ia dibacakan dalam kongres ketiga Far Eastern Association of Tropical Medicine yang diadakan di Saigon, Vietnam dari 8 hingga 15 November 1913. Resolusi tersebut berbunyi:

That in the opinion of this Association it has been proved that beri-beri is caused by a deficiency in diet of certain substances of which the exact nature is still unkown. That such substances are present in sufficient amount in unpolished rice. That therefore it is advised that the Governments of those countries where rice forms the staple article of diet should encourage by all possible means the use of unpolished rice. ${ }^{47}$

Sehingga Perang Dunia Pertama, keputusan ini adalah muktamad tentang punca beri-beri. 
Jadual 2: Statistik Penyakit Beri-Beri di NNMB, 1896-1914

\begin{tabular}{|c|c|c|c|}
\hline Tahun & Kes Yang Dirawat & Kes Kematian & Peratus Kematian (\%) \\
\hline 1896 & 11,953 & 1,763 & 14.8 \\
1897 & 10,638 & 1,704 & 16.0 \\
1898 & 6,619 & 627 & 9.5 \\
1899 & 6,328 & 752 & 11.9 \\
1900 & 11,072 & 1,450 & 13.1 \\
1901 & 8,174 & 1,149 & 14.1 \\
1902 & 7,387 & 1,006 & 13.6 \\
1903 & 7,413 & 1,163 & 15.7 \\
1904 & 8,222 & 1,588 & 19.3 \\
1905 & 7,138 & 1,156 & 16.2 \\
1906 & 6,140 & 1,402 & 22.8 \\
1907 & 5,307 & 1,257 & 23.7 \\
1908 & 9,790 & 1,811 & 18.5 \\
1909 & 5,469 & 658 & 12.0 \\
1910 & 5,562 & 514 & 9.2 \\
1911 & 6,042 & 695 & 11.5 \\
1912 & 5,676 & 657 & 11.6 \\
1913 & 6,409 & 716 & 11.2 \\
1914 & 6,240 & 686 & 11.0 \\
\hline Jumlah & $\mathbf{1 4 1 , 5 7 9}$ & $\mathbf{2 0 , 7 5 4}$ & $\mathbf{1 4 . 7}$ \\
\hline
\end{tabular}

Sumber: Disesuaikan daripada FMSAR 1908, hlm. 28; FMSAR 1909, hlm. 27; FMSAR 1912, hlm. 32; FMSAR 1913, hlm. 29.

Statistik jadual di atas menunjukkan ancaman penyakit beri-beri yang sangat berbahaya. Antara tahun 1896 hingga 1914, jumlah kes yang dirawat adalah 141,579 orang dan kes kematian adalah 20,754 orang. Jika dilihat pada peratusan kematian tahun 1910 adalah yang paling rendah iaitu 9.2\%. Ia menurun agak ketara berbanding dengan tahun 1907 yang peratus kematian adalah $23.7 \%$.

Jadual 3: Statistik Beri-Beri di Perak, Selangor, Negeri Sembilan dan Pahang, 1896-1914

\begin{tabular}{|c|c|c|c|c|c|c|c|c|c|c|c|c|}
\hline \multirow{2}{*}{ Tahun } & \multicolumn{3}{|c|}{ Perak } & \multicolumn{3}{|c|}{ Selangor } & \multicolumn{2}{c|}{ Negeri Sembilan } & \multicolumn{3}{c|}{ Pahang } \\
\cline { 2 - 12 } & Kes & Maut & $\%$ & Kes & Maut & $\%$ & Kes & Maut & $\%$ & Kes & Maut & $\%$ \\
\hline 1896 & 5,357 & 652 & 12.2 & 5,518 & 990 & 17.9 & 1,052 & 109 & 10.4 & 26 & 12 & 46.2 \\
1897 & 4,551 & 482 & 10.6 & 4,884 & 1,066 & 21.8 & 1,033 & 88 & 8.5 & 170 & 68 & 40.0 \\
1898 & 3,945 & 327 & 8.3 & 1,870 & 244 & 13.1 & 603 & 41 & 6.8 & 201 & 15 & 7.5 \\
1899 & 3,113 & 333 & 10.7 & 1,837 & 333 & 18.1 & 1,193 & 55 & 4.6 & 185 & 31 & 16.7 \\
1900 & 6,737 & 994 & 14.8 & 2,428 & 390 & 16.1 & 1,749 & 48 & 2.7 & 158 & 18 & 11.4 \\
1901 & 4,760 & 741 & 15.6 & 2,065 & 311 & 15.1 & 1,104 & 45 & 4.1 & 245 & 52 & 21.2 \\
1902 & 3,689 & 556 & 15.1 & 2,673 & 325 & 12.2 & 881 & 81 & 9.2 & 144 & 44 & 30.6 \\
1903 & 4,203 & 696 & 16.6 & 1,912 & 351 & 18.4 & 1,141 & 81 & 7.1 & 157 & 35 & 22.3 \\
1904 & 4,414 & 1,143 & 25.9 & 2,083 & 326 & 15.7 & 1,506 & 82 & 5.4 & 219 & 37 & 16.9 \\
1905 & 3,334 & 707 & 21.2 & 2,215 & 330 & 14.9 & 1,188 & 52 & 4.4 & 401 & 67 & 16.7 \\
1906 & 2,785 & 886 & 31.8 & 1,896 & 365 & 19.3 & 1,010 & 75 & 7.4 & 449 & 76 & 16.9 \\
1907 & 1,957 & 752 & 38.4 & 1,887 & 374 & 19.8 & 1,055 & 68 & 6.5 & 408 & 63 & 15.4 \\
1908 & 3,618 & 838 & 23.2 & 3,462 & 762 & 22.0 & 2,131 & 158 & 7.4 & 579 & 53 & 9.2 \\
1909 & 1,778 & 184 & 10.4 & 2,055 & 398 & 19.4 & 1,187 & 34 & 2.9 & 449 & 42 & 9.4 \\
1910 & 1,622 & 159 & 9.8 & 1,979 & 221 & 11.2 & 1,637 & 106 & 6.5 & 324 & 28 & 8.6 \\
1911 & 1,615 & 165 & 10.2 & 2,220 & 307 & 13.8 & 1,988 & 204 & 10.3 & 219 & 19 & 8.7 \\
1912 & 1,601 & 168 & 10.5 & 2,282 & 302 & 13.2 & 1,528 & 161 & 10.5 & 265 & 26 & 9.8 \\
1913 & 1,666 & 168 & 10.1 & 2,136 & 303 & 14.2 & 2,188 & 201 & 9.2 & 419 & 44 & 10.5 \\
\hline
\end{tabular}




\begin{tabular}{|c|c|c|c|c|c|c|c|c|c|c|c|c|}
\hline 1914 & 1,573 & 193 & 12.3 & 2,125 & 259 & 12.2 & 2,085 & 187 & 9.0 & 457 & 47 & 10.3 \\
& & & & & & & & & & & & \\
\hline JUMLAH & $\mathbf{6 2 , 3 1 8}$ & $\mathbf{1 0 , 1 4 4}$ & $\mathbf{1 6 . 3}$ & $\mathbf{4 7 , 5 2 7}$ & $\mathbf{7 , 9 5 7}$ & $\mathbf{1 6 . 7}$ & $\mathbf{2 6 , 2 5 9}$ & $\mathbf{1 , 8 7 6}$ & $\mathbf{7 . 1}$ & $\mathbf{5 , 4 7 5}$ & $\mathbf{7 7 7}$ & $\mathbf{1 4 . 2}$ \\
\hline
\end{tabular}

Sumber: Disesuaikan daripada Laporan Tahunan dan Laporan Perubatan Perak, Selangor, Negeri SembilandanPahang, 1896-1914: PKAR 1905, h.xv PKAR1907, h.xv; PKAR 1909, h. xviii; PKAR 1911, $h$. xv; PKAR 1912, h.xv; PKAR 1914, h. xv; SAR 1905, h. xxiv; SAR1907, h. xiv; SAR 1909, h. xvii; SAR 1912, h.xvii; SAR 1914, h.xvii; NSAR 1896, h. 29; NSAR 1903, h.xix; NSAR 1904, h. xix; NSAR 1905, h. xix; NSAR 1907, h. xii; NSAR 1909, h.xvi; NSAR 1911, h.xv; NSAR 1913, h. 19; NSAR 1914, h. 18; PHGMR 1898, h. 4-5; PHGAR 1900, h. xii; PHGAR 1905, h. xvi; PHGAR 1907, h. xiv; PHGAR 1909, h.xiii; PHGAR 1911, h.xiii; PHGAR 1913, h. 20 dan PHGAR 1914, h. 26.

Berdasarkan jadual di atas, antara tahun 1896 hingga 1914 menunjukkan bahawa antara keempat-empat negeri yang terlibat, kes kematian paling tinggi berlaku di negeri Perak iaitu 10,144 orang berbanding dengan Pahang yang hanya mengalami 777 kematian. Hal ini terjadi kerana jumlah kes penyakit beri-beri lebih banyak berlaku di Perak iaitu 62,318 kes, sedangkan di Pahang jumlah kes beri-beri agak kecil iaitu hanya 5,475.

Dari segi kepentingan ekonomi, penemuan dua orang kakitangan IMR pada tahun 1909 iaitu Dr. Fraser dan Dr. Stanton (punca beri-beri adalah akibat kekurangan sejenis bahan dalam beras putih yang dimakan) telah berjaya membantu kerajaan mengawal penyakit ini dari terus merebak. Ini kerana dengan mengetahui penyebab penyakit ini, maka lebih mudah bagi kerajaan mengambil tindakan penyelesaian kepada masalah penyakit beri-beri terutama di kawasan sasaran penyakit. Kawasan sasaran serangan penyakit beri-beri ini pula kawasan perlombongan yang sinonim dengan orang Cina dan penjara. Jadi jelas sekali bahawa penemuan penyelidikan oleh IMR telah dapat menyelesaikan masalah penyakit ini dan seterusnya dapat menjamin pengeluaran hasil bijih timah yang berterusan.

\section{b. Kajian Penyakit Malaria}

Penyakit malaria perlu dikaji kerana dari tahun 1896 hingga tahun 1914, malaria terus memberi ancaman kepada kesihatan penduduk NNMB. Melalui data-data yang diperoleh, malaria mencatatkan kadar kematian yang lebih rendah berbanding dengan beberapa penyakit lain seperti desenteri, diarea, phthisis dan pneumonia. ${ }^{48}$ Namun demikian, pesakit malaria mencatatkan kelompok pesakit paling ramai dirawat di NNMB. Ini kerana dalam tempoh 19 tahun, pesakit malaria berjumlah 297,075 orang berbanding dengan pesakit beriberi 141,579 orang ${ }^{49}$ dan disentri 89,843 orang. ${ }^{50}$ Selain itu, pesakit malaria menyumbang sebanyak 2 peratus daripada pesakit dalam (in-patients) yang dirawat di NNMB antara tahun 1896 hingga 1914 berbanding dengan 11.6 peratus (beri-beri) dan 7.2 peratus (disenteri). ${ }^{51}$

Peranan yang dimainkan oleh IMR dalam penyelidikan malaria di NNMB bermula seawal penubuhan IMR. Artikel pertama yang dimuatkan dalam keluaran sulung Studies from the Institute for Medical Research adalah berkenaan demam malaria. Artikel tersebut yang bertajuk "Malarial Fevers of British Malaya" telah ditulis oleh Dr. Wright, pengarah pertama IMR dan diterbitkan pada tahun 1902.52 Dr. Wright telah membuat kajian sistematik pertama parasit malaria di Tanah Melayu. Beliau menggambarkan spesies yang dijumpai tidak menampilkan kelainan khas malah mempunyai kesamaan dari segi bentuk dan tingkah laku dengan spesies yang dijumpai di Eropah.Beliau banyak belajar tentang demam malaria di wad hospital. Penekanan yang diberikan terhadap penyelidikan malaria dalam kalangan kakitangan institut menjurus kepada vektor dan parasit penyakit tersebut. Pada 
tahun 1909, Dr. Stanton telah melakukan beberapa siri pemeriksaan darah ke atas buruh estet dan mengesan kehadiran parasit malaria dalam kalangan buruh yang sihat. ${ }^{53}$

Pada peringkat awal, penyelidikan vektor malaria dijalankan oleh Dr. Leicester, Penolong Eropah Pertama IMR. ${ }^{54}$ Beliau menumpukan perhatian terhadap nyamuk dan kitaran hidup serangga tersebut. Seterusnya pada tahun 1910, satu kajian tentang penyebaran nyamuk tiruk telah dijalankan di Kuala Lumpur.55 Selain itu, IMR juga bertanggungjawab membuat pengecaman spesis nyamuk tiruk yang dihantar oleh tenaga perubatan negeri. Dalam satu insiden, Dr. Stanton telah berjaya membuat pengecaman spesis nyamuk tiruk yang dihantar oleh Dr. Freer. ${ }^{56}$ Apa yang menghairankan (dan tidak dapat diterangkan oleh Dr. Stanton) ialah beliau mendapati terdapat percampuran spesis nyamuk tiruk yang membiak di air kotor dengan air bersih. ${ }^{57}$

Dr. Stanton sendiri turut membuat penyelidikan ke atas jenis-jenis nyamuk tiruk dan larva nyamuk untuk memastikan spesis tempatan yang menyebarkan malaria. ${ }^{8}$ Dalam eksperimen, beliau membiarkan spesimen daripada beberapa spesis nyamuk tiruk menggigit pesakit malaria tertian malignan ${ }^{59}$ sebelum dibedah. Walau bagaimanapun, percubaan Dr. Stanton untuk menjangkitkan spesis-spesis ini dengan parasit tertian malignan gagal. Dr. Stanton berpendapat kemungkinan zigot parasit yang sedia ada adalah tertian benigna. ${ }^{60}$ Eksperimen ini menunjukkan spesis nyamuk tiruk yang berpotensi menyebarkan malaria tertian malignan iaitu myzomyia albirostris, nyssorhynchus fuliginosus dan nyssorhynchus maculates dan myzorhynchus sinensis.

Sejak sekian lama, kekeliruan timbul akibat penggunaan pelbagai genera dan sub genera seperti myzomyia, nyssorhynchus, nyssomyzomyia dan myzorhynchus dalam spesis nyamuk tiruk. Pada tahun 1912, Dr. Stanton berpendapat masalah ini dapat diatasi dengan penggunaan genus anopheles. ${ }^{61}$ Justeru, perkataan anopheles terus digunapakai untuk merujuk spesis nyamuk tiruk yang pelbagai.

Sebagai kesinambungan kepada penyelidikan vektor malaria oleh kakitangan IMR, satu jaringan kerjasama diwujudkan dengan kumpulan penyelidik dari beberapa pertubuhan. Antaranya ialah King Institute (Madras), London School of Tropical Medicine, Imperial Bureau of Etomology, British Museum dan United States National Museum. ${ }^{62}$ Dr. Stanton memainkan peranan yang aktif dalam jaringan kerjasama ini. ${ }^{63}$ Di samping itu, usaha turut dijalankan untuk membentuk keseragaman nama-nama spesis nyamuk tiruk dalam lingkungan India-Sumatra-Semenanjung Tanah Melayu-Filipina-Formosa-Indochina. ${ }^{64}$

Selain tenaga perubatan negeri, kakitangan IMR juga melakukan kajian terhadap parasit malaria. Pada tahun 1909, Dr. Stanton telah melakukan beberapa siri pemeriksaan darah ke atas buruh estet dan mengesan kehadiran parasit malaria dalam kalangan buruh yang sihat. ${ }^{65}$ Hasil penyelidikan yang dibuat menunjukkan 23 kes kematian daripada 164 kes kematian yang dibedah siasat oleh kakitangan IMR disahkan berpunca daripada parasit malaria sub-tertain. 66

Sebagai tenaga yang mengkhusus dalam kajian saintifik tentang malaria, kakitangan IMR turut mengetengahkan pandangan mereka terhadap langkah pengawalan malaria yang dijalankan oleh tenaga perubatan negeri. Dalam hal ini, Dr. Henry Fraser, pengarah ketiga IMR mengemukakan pandangan beliau berkenaan beberapa perkara, antaranya ialah kepentingan penggunaan kuinina secara sistematik dan kuaters kalis-nyamuk untuk buruh estet; kesesuaian kaedah penyaliran untuk kawasan bandar berbanding kawasan pedalaman; keperluan untuk menyelidik dengan lebih mendalam keberkesanan penggunaan sejenis ikan dari Berbados iaitu millions sebagai agen penghapus larva nyamuk ${ }^{67}$ dan ketidaksesuaian kaedah penyemburan minyak kerosin di atas permukaan kolam yang kecil. ${ }^{68}$ Pandangan paling bernas yang beliau utarakan idalah berkenaan kaedah sistem penyaliran dan penggunaan kuinina yang menimbulkan kontroversi dalam kalangan tenaga perubatan. Dr. Fraser menyatakan, "A controversy has recently arisen on drainage versus 
quinine prophylaxis, it would be futile to enter into such a controversy for a method which gave execellent results in one place might prove quite impracticable in another" ${ }^{69}$

Jadual 4: Statistik Penyakit Malaria di Negeri-Negeri Melayu Bersekutu, 1896-1914

\begin{tabular}{|c|c|c|c|}
\hline Tahun & Kes yang Dirawat & Kes Kematian & Peratus Kematian (\%) \\
\hline 1896 & 6,108 & 405 & 6.6 \\
1897 & 6,325 & 434 & 6.9 \\
1898 & 7,237 & 410 & 5.7 \\
1899 & 7,883 & 284 & 3.6 \\
1900 & 11,554 & 484 & 4.2 \\
1901 & 11,063 & 680 & 6.1 \\
1902 & 7,924 & 464 & 5.9 \\
1903 & 7,829 & 463 & 5.9 \\
1904 & 8,411 & 447 & 5.3 \\
1905 & 9,533 & 502 & 5.3 \\
1906 & 12,174 & 699 & 5.7 \\
1907 & 19,706 & 1,317 & 6.7 \\
1908 & 18,411 & 1,234 & 6.7 \\
1909 & 17,386 & 936 & 5.4 \\
1910 & 23,824 & 1,092 & 4.6 \\
1911 & 31,362 & 1,833 & 5.8 \\
1912 & 29,362 & 1,744 & 5.9 \\
1913 & 31,256 & 1,931 & 6.2 \\
1914 & 29,727 & 1,793 & 6.0 \\
\hline Jumlah & 297,075 & 17,152 & 5.8 \\
\hline
\end{tabular}

Sumber: Disesuaikan daripada FMSAR 1908, hlm. 27; FMSAR 1909, hlm. 27; FMSAR 1910, hlm. 2, dalam SFMSGG 1911; FMSMR 1911, hlm. 3, dalam SFMSGG 1912; FMSMR 1914, hlm. 2, dalam SFMSGG 1915.

Berdasarkan jadual di atas, jelas menunjukkan bahawa antara tahun 1896 hingga 1914, peratus kematian paling rendah ialah pada tahun 1899 iaitu hanya 3.6 peratus daripada 7,883 kes dirawat. Manakala jumlah kes malaria yang dirawat paling ramai adalah pada tahun 1911 iaitu berjumlah 31,362 dan mencatatkan kes kematian berjumlah 1,833 orang.

Jadual 5: Statistik Penyakit Malaria di Perak, Selangor, Negeri Sembilan dan Pahang, 1896-1914

\begin{tabular}{|c|c|c|c|c|c|c|c|c|c|c|c|c|}
\hline & \multicolumn{3}{|c|}{ Perak } & \multicolumn{3}{c|}{ Selangor } & \multicolumn{3}{c|}{ Negeri Sembilan } & \multicolumn{3}{c|}{ Pahang } \\
\cline { 2 - 12 } Tahun & Kes & Maut & $\%$ & Kes & Maut & $\%$ & Kes & Maut & $\%$ & Kes & Maut & $\%$ \\
\hline 1896 & 3,951 & 279 & 7.1 & 1,652 & 105 & 6.4 & 505 & 21 & 4.2 & - & - & - \\
1897 & 3,817 & 273 & 7.2 & 1,892 & 134 & 7.1 & 616 & 27 & 4.4 & - & - & - \\
1898 & 4,189 & 228 & 5.4 & 2,070 & 151 & 7.3 & 637 & 20 & 3.1 & 341 & 11 & 3.2 \\
1899 & 4,748 & 201 & 4.2 & 1,872 & 55 & 2.9 & 911 & 16 & 1.8 & 352 & 12 & 3.4 \\
1900 & 6,329 & 167 & 2.6 & 4,064 & 297 & 7.3 & 802 & 13 & 1.6 & 359 & 7 & 1.9 \\
1901 & 4,694 & 285 & 6.1 & 5,445 & 322 & 5.9 & 500 & 30 & 6.0 & 424 & 43 & 10. \\
1902 & 3,920 & 214 & 5.5 & 2,977 & 174 & 5.8 & 584 & 43 & 7.4 & 443 & 33 & 1 \\
1903 & 4,504 & 251 & 5.6 & 1,980 & 153 & 7.7 & 738 & 26 & 3.5 & 607 & 33 & 7.4 \\
1904 & 4,404 & 239 & 5.4 & 2,008 & 114 & 5.7 & 1,358 & 66 & 4.9 & 641 & 28 & 5.4 \\
1905 & 5,442 & 232 & 4.3 & 2,109 & 173 & 8.2 & 1,311 & 67 & 5.1 & 671 & 30 & 4.4 \\
1906 & 4,991 & 220 & 4.4 & 3,397 & 348 & 10.2 & 2,545 & 94 & 3.7 & 1,241 & 37 & 4.5 \\
1907 & 7,063 & 392 & 5.6 & 8,084 & 685 & 8.5 & 3,020 & 169 & 5.6 & 1,539 & 71 & 3.0 \\
1908 & 7,310 & 474 & 6.5 & 6,489 & 526 & 8.1 & 3,010 & 158 & 5.2 & 1,602 & 76 & 4.6 \\
1909 & 7,404 & 426 & 5.8 & 5,522 & 322 & 5.8 & 3,235 & 136 & 4.2 & 1,225 & 52 & 4.7 \\
1910 & 9,241 & 444 & 4.8 & 8,122 & 369 & 4.5 & 4,585 & 207 & 4.5 & 1,876 & 72 & 4.2 \\
1911 & 10,624 & 621 & 5.8 & 10,780 & 728 & 6.8 & 7,821 & 399 & 5.1 & 2,137 & 85 & 3.8 \\
\hline
\end{tabular}




\begin{tabular}{|c|c|c|c|c|c|c|c|c|c|c|c|c|}
\hline 1912 & 11,640 & 708 & 6.1 & 9,910 & 683 & 6.9 & 5,721 & 269 & 4.7 & 2,091 & 84 & 4.0 \\
1913 & 12,849 & 780 & 6.1 & 10,556 & 799 & 7.6 & 5,370 & 239 & 4.5 & 2,481 & 113 & 4.0 \\
1914 & 12,127 & 713 & 5.9 & 10,345 & 765 & 7.4 & 5,083 & 227 & 4.5 & 2,172 & 88 & 4.6 \\
& & & & & & & & & & & & 4.1 \\
\hline JUMLAH & 129,247 & 7,147 & 5.5 & 99,274 & 6,903 & 7.0 & 48,352 & 2,227 & 4.6 & 20,202 & 875 & 4.3 \\
\hline
\end{tabular}

Sumber: Disesuaikan daripada Laporan Tahunan dan Laporan Perubatan Perak, Selangor, Negeri Sembilan dan Pahang, 1896-1914: PKAR 1896, hlm. 47; PKAR 1897, hlm. 40; PKAR 1898, hlm. 49; PKAR 1899, hlm. 46; PKAR 1900, hlm. 50; PKAR 1901, hlm.37; PKAR 1902, hlm.37; PKAR 1903, hlm 32; PKAR 1904, hlm. xii; PKAR 1906, hlm. xv; PKAR 1908, hlm. xix; PKAR 1910, hlm. xvi; PKAR 1912, hlm. xv; PKAR 1914, hlm. xv; SAR 1896, hlm. 33; SAR 1897, hlm. 41; SAR 1898, hlm. 33; SAR 1901, hlm. xxv; SAR 1903, hlm. xvii; SAR 1914, hlm. xvii; NSAR 1896, hlm. 29; NSAR 1897, hlm. 25; NSAR 1898, hlm. xiv; NSAR 1899, hlm. xvi; NSAR 1900, hlm. xvi; NSAR 1901, hlm. xvii; NSAR 1903, hlm. xxiii; NSAR 1904, hlm. xix; NSAR 1905, hlm. xix; NSAR 1907, hlm. xii; NSAR 1909, hlm. xvi; NSAR 1911, hlm. xv; NSAR 1912, hlm. xv; NSAR 1914, hlm. 18; PHGMR 1898, hlm 4-5; PHGAR 1899, hlm xiv; PHGAR 1900, hlm. xii; PHGAR 1900, hlm. xii; PHGAR 1901, hlm. xii; PHGAR 1902, hlm. xii; PHGAR 1903, hlm. xii; PHGAR 1904, hlm. xi; PHGAR 1905, hlm. xvi; PHGAR 1907, hlm. xiv; PHGAR 1908, hlm. xiv; PHGAR 1910, hlm. xiii; PHGAR 1912, hlm. xiii dan PHGAR 1914, hlm. 26.

Berdasarkan statistik di atas, jelas menunjukkan bahawa kes malaria paling tinggi adalah di negeri Perak yang mencatatkan 129,247 kes. Jumlah kes tersebut jauh lebih rendah jika dibandingkan dengan negeri Pahang yang hanya mencatatkan 20,202 kes rawatan malaria.

Demi kepentingan ekonomi dan sosial, kerajaan telah mengambil langkah pengawalan penyakit malaria melalui kerjasama tiga pihak. IMR dan tenaga perubatan negeri (tumpuan kepada penyelidikan dan pengawalan parasit dan vektor penyakit) dan kerajaan persekutuan bertindak menubuhkan sebuah badan yang dikenali sebagai Lembaga Penasihat Malaria yang mengawal selia kerja-kerja pengawalan malaria. ${ }^{70}$ Berdasarkan penyelidikan IMR, telah dikenalpasti bahawa lokasi sasaran serangan penyakit malaria adalah kawasan yang baru dibuka dan lazimnya berkaitan dengan penerokaan dan pembersihan hutan untuk penanaman getah. ${ }^{71}$ Kelompok sasaran malaria pula melibatkan kelompok pendatang baru khasnya yang bekerja di kawasan yang baru dibuka untuk penanaman iaitu buruh Tamil yang mempunyai tahap imun yang rendah berbanding dengan kelompok buruh Jawa.72 Pengawalan penyakit yang dijalankan oleh IMR sangat penting kerana dalam tempoh 19 tahun (1896-1914), pesakit malaria berjumlah 297,075 orang. ${ }^{73}$ Kejayaan IMR paling penting dalam mengawal penyakit ini daripada terus menular adalah penggunaan kuinin secara sistematik dan kuarters kalis-nyamuk untuk buruh estet. Penemuan ini sudah pasti telah membantu kerajaan meningkatkan kesihatan buruh ladang dan seterusnya menjamin penghasilan getah yang maksimum.

\section{c. Kajian Penyakit Disenteri}

Selain penyakit beri-beri dan malaria, penyakit disenteri merupakan salah satu penyakit utama yang menyebabkan kemasukan pesakit ke hospital kerajaan setiap tahun. Antara tahun 1888 hingga 1895 (bagi Perak [jumlah pesakit dirawat ialah 13,1081 orang dan jumlah kematian 19,262 orang], Selangor [jumlah pesakit dirawat ialah 57,964 orang dan jumlah kematian 9,422 orang] dan Negeri Sembilan [jumlah pesakit dirawat ialah 2,882 orang dan jumlah kematian 263 orang] $)^{74}$ didapati bahawa kemasukan pesakit akibat disenteri tidak melebihi 20 peratus daripada jumlah keseluruhan kemasukan pesakit. Peratusan ini adalah lebih rendah berbanding dengan beri-beri dan malaria. ${ }^{75}$ Walau bagaimanapun, peratus kematian yang dicatatkan adalah lebih tinggi daripada malaria iaitu hampir 20 peratus (kecuali tahun 1888 dan 1889) berbanding bagi malaria yang tidak melebihi 9 peratus. Justeru itu, dalam tempoh 1888 hingga 1895, disenteri menjadi penyakit kedua utama di NNMB selepas beri-beri. ${ }^{76}$ Oleh sebab itu, IMR dan pemerintah British berpendapat 
penyakit ini perlu dikaji penyebab dan cara untuk menanganinya. British bimbang penyakit ini menjejaskan kesihatan masyarakat terutama buruh imigran yang menjadi elemen penting dalam ekonomi British.

Penyelidikan serius yang dilakukan oleh kakitangan IMR terhadap jenis disenteri adalah lewat berbanding dengan beri-beri dan malaria. Walaupun Dr. R.S. Milne terlibat dalam kajian bakteriologi disenteri yang pelbagai seawal tahun 1903,77 tetapi penyelidikan terhadap disenteri ameba hanya dijalankan pada tahun 1913,78 manakala ciri-ciri disenteri basilus pada tahun berikutnya. ${ }^{79}$ Sehingga tahun 1913, penyelidikan lanjutan terhadap disenteri basilus masih diperlukan. Hal ini telah dilaporkan dalam Laporan Tahunan Negeri-negeri Melayu Bersekutu, 1913 bahawa, "Further investigations will perhaps furnish us with the other types of dysentery bacilli and it is hoped to prepare a serum or sera for use in cases of bacillary dysentery.

\section{Jadual 6: Statistik Penyakit Disenteri di Negeri-Negeri Melayu Bersekutu, 1896-1914}

\begin{tabular}{|c|c|c|c|}
\hline Tahun & Kes yang Dirawat & Kes Kematian & Peratus Kematian \\
\hline 1896 & 3,151 & 1,037 & 32.9 \\
1897 & 2,805 & 839 & 29.9 \\
1898 & 2,367 & 653 & 27.6 \\
1899 & 2,336 & 580 & 24.8 \\
1900 & 4,806 & 1,356 & 28.2 \\
1901 & 5,122 & 1,560 & 30.5 \\
1902 & 3,403 & 1,094 & 32.1 \\
1903 & 3,208 & 1,086 & 33.9 \\
1904 & 3,041 & 954 & 31.4 \\
1905 & 4,780 & 1,281 & 26.8 \\
1906 & 5,561 & 1,679 & 30.2 \\
1907 & 6,030 & 2,133 & 35.4 \\
1908 & 7,590 & 2,509 & 33.1 \\
1909 & 5,432 & 1,425 & 26.2 \\
1910 & 5,230 & 1,234 & 23.6 \\
1911 & 7,225 & 2,131 & 29.5 \\
1912 & 6,215 & 1,699 & 27.3 \\
1913 & 5,559 & 1,326 & 23.9 \\
1914 & 5,982 & 1,429 & 23.9 \\
\hline Jumlah & 89,843 & 26,005 & 28.9 \\
\hline
\end{tabular}

Sumber: Disesuaikan daripada Laporan Tahunan dan Laporan Perubatan Perak, Selangor, Negeri Sembilan dan Pahang, 1896-1914: PKAR 1896, hlm. 47; PKAR 1897, hlm. 40; PKAR 1898, hlm. 49; PKAR 1899, hlm. 46; PKAR 1900, hlm. 50; PKAR 1901, hlm. 37; PKAR 1902, hlm. 37; PKAR 1903, hlm. 32; PKAR 1904, hlm. xii; PKAR 1906, hlm. xv; PKAR 1908, hlm. xix; PKAR 1910, hlm. xvi; PKAR 1912, hlm. xv; PKAR 1914, hlm. xv; SAR 1896, hlm. 33; SAR 1897, hlm. 41; SAR 1898, hlm. 33; SAR 1901, hlm. xxv; SAR 1903, hlm. xvii; SAR 1914, hlm. xvii; NSAR 1896, hlm. 29; NSAR 1897, hlm. 25; NSAR 1898, hlm. xiv; NSAR 1899, hlm.xvi; NSAR 1900, hlm. xvi; NSAR 1901, hlm. xvii; NSAR 1903, hlm. xxiii; NSAR 1904, hlm. xix; NSAR 1905, hlm. xix; NSAR 1907, hlm. xii; NSAR 1909, hlm. xvi; NSAR 1911, hlm. xv; NSAR 1912, hlm. xv; NSAR 1914, hlm. 18; PHGMR 1898, hlm. 4-5; PHGAR 1899, hlm. xiv; PHGAR 1900, hlm. xii; PHGAR 1900, hlm. xii; PHGAR 1901, hlm. xii; PHGAR 1902, hlm. xii; PHGAR 1903, hlm. xii; PHGAR 1904, hlm. xi; PHGAR 1905, hlm. xvi; PHGAR 1907, hlm. xiv; PHGAR 1908, hlm. xiv; PHGAR 1910, hlm. xiii; PHGAR 1912, hlm. xiii dan PHGAR 1914, hlm. 26.

Berdasarkan jadual di atas, peratusan kematian yang paling tinggi antara tahun 1896 hingga 1914 adalah pada tahun 1907 iaitu sebanyak 35.4 peratus. Walau bagaimanapun, peratusan ini menurun pada tahun 1914 iaitu hanya 23.9 peratus sahaja. Penurunan peratusan kematian ini sudah pasti hasil sumbangan penyelidikan daripada IMR. 
Jadual 7: Statistik Penyakit Disenteri di Perak, Selangor, Negeri Sembilan dan Pahang, 1896-1914

\begin{tabular}{|c|c|c|c|c|c|c|c|c|c|c|c|c|}
\hline & \multicolumn{3}{|c|}{ Perak } & \multicolumn{3}{c|}{ Selangor } & \multicolumn{2}{c|}{ Negeri Sembilan } & \multicolumn{3}{|c|}{ Pahang } \\
\cline { 2 - 12 } & Kes & Maut & $\%$ & Kes & Maut & $\%$ & Kes & Maut & $\%$ & Kes & Maut & $\%$ \\
\hline 1896 & 1,854 & 594 & 32.0 & 1,174 & 404 & 34.4 & 123 & 39 & 31.7 & - & - & - \\
1897 & 1,727 & 461 & 26.7 & 904 & 318 & 35.2 & 174 & 60 & 34.5 & - & - & - \\
1898 & 1,363 & 308 & 22.6 & 781 & 300 & 38.4 & 123 & 22 & 17.9 & 100 & 23 & 23.0 \\
1899 & 1,407 & 342 & 24.3 & 659 & 188 & 28.5 & 187 & 33 & 17.6 & 83 & 17 & 20.5 \\
1900 & 3,220 & 899 & 27.9 & 1,245 & 396 & 31.8 & 219 & 44 & 20.1 & 122 & 17 & 13.9 \\
1901 & 2,854 & 1,019 & 35.7 & 1,527 & 398 & 26.1 & 591 & 96 & 16.2 & 150 & 47 & 31.3 \\
1902 & 2,013 & 631 & 31.3 & 973 & 320 & 32.9 & 286 & 115 & 40.2 & 131 & 28 & 21.4 \\
1903 & 2,041 & 700 & 34.3 & 638 & 229 & 35.9 & 407 & 120 & 29.5 & 122 & 37 & 30.3 \\
1904 & 1,853 & 614 & 33.1 & 599 & 183 & 30.6 & 460 & 120 & 26.1 & 129 & 37 & 28.7 \\
1905 & 3,031 & 816 & 26.1 & 958 & 303 & 31.6 & 486 & 111 & 22.8 & 305 & 51 & 16.7 \\
1906 & 2,599 & 775 & 29.8 & 1,224 & 437 & 35.7 & 1,232 & 342 & 27.8 & 506 & 125 & 24.7 \\
1907 & 2,870 & 838 & 29.2 & 1,262 & 583 & 46.2 & 1,571 & 633 & 40.3 & 327 & 79 & 24.2 \\
1908 & 3,715 & 1,179 & 31.7 & 2,324 & 801 & 34.5 & 1,253 & 455 & 36.3 & 298 & 74 & 24.8 \\
1909 & 3,100 & 769 & 24.8 & 1,041 & 381 & 36.6 & 1,019 & 229 & 22.5 & 272 & 46 & 16.9 \\
1910 & 2,848 & 577 & 20.3 & 1,175 & 373 & 31.7 & 966 & 236 & 24.4 & 241 & 48 & 19.9 \\
1911 & 3,376 & 773 & 22.9 & 1,609 & 515 & 32.0 & 2,042 & 815 & 39.9 & 198 & 28 & 14.1 \\
1912 & 3,049 & 693 & 22.7 & 1,540 & 478 & 31.0 & 1,342 & 484 & 36.1 & 284 & 44 & 15.5 \\
1913 & 2,991 & 672 & 22.5 & 1,455 & 395 & 27.1 & 854 & 217 & 25.4 & 259 & 42 & 16.1 \\
1914 & 3,231 & 700 & 21.7 & 1,570 & 421 & 26.8 & 926 & 267 & 28.8 & 255 & 41 & 16.1 \\
\hline JUMLAH & 49,142 & 13,360 & 27.2 & 22,658 & 7,423 & 32.8 & 14,261 & 4,438 & 31.1 & 3,782 & 784 & 20.7 \\
\hline
\end{tabular}

Sumber: Disesuaikan daripada Laporan Tahunan dan Laporan Perubatan Perak, Selangor, Negeri Sembilan dan Pahang, 1896-1914: PKAR 1896, hlm. 47; PKAR 1897, hlm. 40; PKAR 1898, hlm. 49; PKAR 1899, hlm. 46; PKAR 1900, hlm. 50; PKAR 1901, hlm. 37; PKAR 1902, hlm. 37; PKAR 1903, hlm. 32; PKAR 1904, hlm. xii; PKAR 1906, hlm. xv; PKAR 1908, hlm. xix; PKAR 1910, hlm. xvi; PKAR 1912, hlm. xv; PKAR 1914, hlm. xv; SAR 1896, hlm. 33; SAR 1897, hlm. 41; SAR 1898, hlm. 33; SAR 1901, hlm. xxv; SAR 1903, hlm. xvii; SAR 1914, hlm. xvii; NSAR 1896, hlm. 29; NSAR 1897, hlm. 25; NSAR 1898, hlm. xiv; NSAR 1899, hlm. xvi; NSAR 1900, hlm. xvi; NSAR 1901, hlm. xvii; NSAR 1903, hlm. xxiii; NSAR 1904, hlm. xix; NSAR 1905, hlm. xix; NSAR 1907, hlm. xii; NSAR 1909, hlm. xvi; NSAR 1911, hlm. xv; NSAR 1912, hlm. xv; NSAR 1914, hlm. 18; PHGMR 1898, hlm. 4-5; PHGAR 1899, hlm. xiv; PHGAR 1900, hlm. xii; PHGAR 1900, hlm. xii; PHGAR 1901, hlm. xii; PHGAR 1902, hlm. xii; PHGAR 1903, hlm. xii; PHGAR 1904, hlm. xi; PHGAR 1905, hlm. xvi; PHGAR 1907, hlm. xiv; PHGAR 1908, hlm. xiv; PHGAR 1910, hlm. xiii; PHGAR 1912, hlm. xiii dan PHGAR 1914, hlm. 26.

Dalam jadual di atas, peratus kes kematian penyakit disenteri paling tinggi berlaku di negeri Selangor iaitu 46.2 peratus, diikuti oleh Negeri Sembilan, negeri Perak iaitu 34.3 peratus dan negeri Pahang iaitu 30.3 peratus. Walau bagaimanapun, peratusan ini menunjukkan penurunan pada tahun 1914, peratus kematian bagi penyakit ini di negeri Selangor menurun menjadi 26.8 peratus. Pada tahun yang sama, kes penyakit disenteri di Negeri Sembilan menurun menjadi 28.8 peratus, di negeri Perak statistik penyakit disenteri menurun menjadi 21.7 peratus dan di negeri Pahang pula menurun menjadi 16.1 peratus. Penurunan kes kematian dalam tempoh tersebut sudah pasti atas usaha dan sumbangan penyelidikan yang dibuat oleh IMR.

Jadual 8: Jumlah Pesakit dalam Hospital di NNMB, 1986-1913

\begin{tabular}{|c|c|c|c|c|c|}
\hline Tahun & $\begin{array}{c}\text { Perak } \\
\text { (Orang) }\end{array}$ & $\begin{array}{c}\text { Selangor } \\
\text { (Orang) }\end{array}$ & $\begin{array}{c}\text { Negeri } \\
\text { Sembilan } \\
\text { (Orang) }\end{array}$ & $\begin{array}{c}\text { Pahang } \\
\text { (Orang) }\end{array}$ & $\begin{array}{c}\text { Jumlah } \\
\text { (Orang) }\end{array}$ \\
\hline 1896 & 24,486 & 17,709 & 3,270 & 1,356 & 46,821 \\
1897 & 23,024 & 16,608 & 3,324 & 1,451 & 44,407 \\
1898 & 23,297 & 12,705 & 3,128 & 1,195 & 40,325 \\
\hline
\end{tabular}




\begin{tabular}{|c|c|c|c|c|c|}
\hline 1899 & 22,276 & 12,371 & 4,007 & 1,075 & 39,729 \\
1900 & 31,579 & 17,963 & 5,016 & 1,218 & 55,776 \\
1901 & 27,293 & 21,351 & 5,280 & 1,720 & 55,644 \\
1902 & 23,703 & 18,173 & 4,453 & 1,894 & 48,223 \\
1903 & 26,201 & 14,425 & 5,250 & 2,008 & 47,884 \\
1904 & 24,822 & 14,319 & 7,162 & 2,206 & 48,509 \\
1905 & 29,226 & 16,382 & 6,924 & 2,984 & 55,516 \\
1906 & 27,178 & 18,963 & 8,948 & 4,226 & 59,315 \\
1907 & 30,751 & 25,602 & 10,401 & 4,543 & 71,297 \\
1908 & 35,595 & 30,287 & 12,884 & 5,339 & 84,105 \\
1909 & 33,725 & 22,889 & 12,050 & 4,528 & 73,192 \\
1910 & 36,501 & 25,082 & 13,944 & 5,297 & 80,824 \\
$1911^{*}$ & & & & & \\
1912 & 42,062 & 32,171 & 17,399 & 5,525 & 97,162 \\
1913 & 45,349 & 32,173 & 17,064 & 6,074 & 100,660 \\
1914 & 45,595 & 31,754 & 17,054 & 6,211 & 100,614 \\
\hline Jumlah & 552,663 & 380,927 & 157,558 & 58,850 & $1,150,003$ \\
\hline
\end{tabular}

* Data tidak lengkap

Sumber: Dipetik dan disesuaikan daripada Noraini Mohamed Hassan, "Penyakit Tropika di Negerinegeri Melayu Bersekutu, 1896-1914: Tumpuan Kepada Penyakit Beri-beri, Malaria dan Penyakit Usus", Disertasi M.A., Universiti Malaya, 2004, hlm. 177-178. Lihat juga PKAR 1919, hlm. 9; PKAR 1920, hlm. 9; SAR 1920, hlm. 7; NSAR 1919, hlm. 14; PHGAR 1920, hlm. 14; FMS Medical Report 1913, hlm. 1; FMS Medical Report 1914, hlm. 9; FMS Medical Report 1915, hlm. 4; FMS Medical Report 1916, hlm. 3; FMS Medical Report 1917, hlm. 2; FMS Medical Report 1918, hlm. 3; FMS Medical Report 1920, hlm. 5; FMS Medical Report 1921, hlm. 5; FMS Medical Report 1922, hlm. 8; FMS Medical Report 31st December, 1923, hlm. 3; FMS Medical Report 31st December 1924; FMSAR 1925, hlm. 4; FMSAR 31st December 1926, hlm. 11; Annual Report of the Medical Department 31st December 1927, hlm. 13.

Dalam jadual di atas, berlaku peningkatan pesakit dalam hospital-hospital di NNMB antara tahun 1896 hingga 1914. Pada tahun 1896, jumlah pesakit di hospital hanya 46,821 orang berbanding dengan 100,614 orang pada tahun 1914. Hal ini disebabkan kepesatan pembangunan yang berlaku di NNMB yang telah mendorong kemasukan imigran luar untuk datang mengusahakan sektor bijih timah dan getah. Jadi hal ini telah menyebabkan berlaku peningkatan jumlah penduduk yang sangat ketara.

Dari segi ekonomi, tempoh masa 1896-1914 merupakan masa yang sangat mencabar kerana elemen penting dalam perusahaan iaitu buruh lombong dan getah berhadapan dengan masalah serangan penyakit. Bagi IMR pula, pada tempoh masa yang sama dianggap penting kerana dikatakan sebagai fasa pertama serangan dan penularan penyakit tropika di NNMB. ${ }^{80}$ Tempoh ini merupakan tempoh eksperimen pemerintah British dalam usaha mengawal penyakit dengan mengadakan peruntukan kewangan kepada IMR bagi membuat penyelidikan untuk meningkatkan pengetahuan tentang penyakit tropika seperti malaria, beri-beri dan disenteri yang mempunyai kesan secara langsung ke atas tenaga buruh Cina di sektor perlombongan dan buruh India di sektor perladangan. ${ }^{81}$ Penyelidikan yang dijalankan oleh IMR banyak membantu pihak kerajaan untuk mencari jalan bagi menangani masalah penyakit dalam kalangan buruh untuk menjamin perkembangan perusahaan bijih timah dan getah. Pada tahun 1909, IMR telah menyumbang kepada penemuan punca beriberi, iaitu penyakit itu disebabkan oleh kekurangan nutrien penting yang terhasil daripada penggunaan beras yang telah digiling berlebihan. ${ }^{82}$ Di peringkat inilah, kerajaan persekutuan campur tangan. Pada tahun yang sama kerajaan persekutuan mengisytiharkan pemberhentian penggunaan beras putih di semua institusi kerajaan. ${ }^{83}$ Tindakan ini berjaya meneruskan kelangsungan ekonomi British di Tanah Melayu. 


\section{Kepentingan Kajian IMR Terhadap Ekonomi British}

Penubuhan Persekutuan pada tahun 1896 telah menyebabkan berlaku perkembangan pesat dalam pelbagai bidang terutama dari sudut ekonomi. Perkembangan ini secara tidak langsung telah mendorong peningkatan jumlah penduduk terutama dengan kemasukan imigran Cina dan India. Peningkatan jumlah penduduk ini telah menimbulkan masalah sosial dan kesihatan. Pada awalnya, British kurang memberikan perhatian terhadap masalah tersebut sehingga muncul kesedaran bahawa masalah kesihatan dalam kalangan penduduk terutamanya buruh Cina dan India boleh menjejaskan ekonomi mereka. Sejak tahun 1886, peruntukan perkhidmatan hospital di Tanah Melayu adalah tanggungjawab pemilik estet. Ini termasuk penyediaan tempat tinggal, perkhidmatan perubatan dan penawaran ubatubatan berkualiti tinggi yang mencukupi. ${ }^{84}$ British hanya mulai memberi perhatian terhadap isu ini apabila golongan pemodal mulai menyuarakan rasa tidak puas hati terhadap sikap sambil lewa oleh pentadbiran British. Sikap pentadbiran British terhadap perkara ini bertitik-tolak daripada ketetapan awal bahawa isu pekerja di kawasan pengeluaran ekonomi khususnya dalam perlombongan dan pertanian diserahkan kepada para pemodal. Namun sikap British berubah apabila berlaku kemelesetan ekonomi dan penyakit berjangkit yang meragut banyak nyawa. Kepesatan penduduk ini juga menyebabkan kadar kematian di ladang getah meningkat.

Ramai pesakit dan kematian dilaporkan di kawasan lombong dan estet disebabkan oleh persekitaran, jenis pekerjaan, tempat tinggal dan juga pemakanan. Pesakit dan kematian di luar kawasan pusat ekonomi jarang dilaporkan. Penyakit yang banyak menyebabkan kematian ialah penyakit beri-beri, cirit-birit (diarrhea, dysentery), malaria, cacar, cholera, batuk kering (tuberculosis) dan hawar (plague). 85

Jumlah kematian yang banyak dalam kalangan buruh semestinya menjejaskan pengeluaran hasil ekonomi. Justeru, mereka mula memperkenalkan dasar untuk mengawal dan membasmi penyakit mulai tahun 1890-an. Beberapa pakar perubatan telah dipanggil dari Britain untuk mengkaji dan mengenal pasti sebab penyakit, dan dari situ mereka membuat langkah yang diperlukan untuk mengatasinya. Keputusan menubuhkan IMR pada tahun 1900 di Kuala Lumpur telah menjadi titik-tolak penting oleh pemerintah British untuk mencari penyelesaian terhadap penyakit tropika yang menjejaskan kepentingan ekonomi mereka. IMR telah menjadi salah sebuah institut penyelidikan perubatan mengenai penyakit tropika yang terkenal di peringkat antarabangsa. Pada tahun 1905, Singapore Medical School telah ditubuhkan sebelum diberi nama King Edward VII College of Medicine. Kolej ini sangat penting kerana berperanan melatih doktor-doktor tempatan. ${ }^{86}$

Langkah yang diambil oleh kerajaan British untuk memperbaiki taraf kesihatan penduduk di Tanah Melayu kemudian telah berjaya menurunkan kadar kematian dalam kalangan penduduk terutamanya dalam kalangan buruh lombong dan ladang getah. Apabila kesihatan tenaga buruh terjaga, maka secara tidak langsung dapat menjamin pengeluaran hasil bahan mentah menjadi lebih baik. Dalam hal ini, keuntungan yang boleh diperoleh oleh kerajaan British di Tanah Melayu menjadi lebih optimum. Menjelang Perang Dunia Kedua, terdapat lebih 70 buah hospital kerajaan dan swasta di seluruh Tanah Melayu dan Singapura.

Pada tahun 1911, jumlah kematian buruh ladang adalah 9,040 orang atau 62 peratus dari jumlah keseluruhan pekerja dalam sektor ini; 87 pada tahun 1912, jumlah buruh ladang yang meninggal adalah 7,054 orang atau 41.0 peratus; pada tahun 1918, jumlah kematian buruh ladang adalah 9,080 orang atau 42.6 peratus, tetapi pada tahun 1921 keadaan ini menurun kepada 3,195 orang atau 18.2 peratus sahaja. ${ }^{88}$ Keadaan ini bertambah baik pada tahun 1930-an apabila hospital di estet menyediakan tempat tidur dan khidmat kesihatan yang lebih baik. Ini membawa kepada penurunan kadar kematian di estet getah. 
Jadual 9: Kadar Kematian di Estet Getah Tanah Melayu

\begin{tabular}{|l|c|c|c|}
\hline \multicolumn{1}{|c|}{ Estet Getah Terpilih di TM } & 1911 & 1923 & 1932 \\
\hline Ekar & 1,632 & 2,650 & 6,801 \\
Purata tenaga kerja India & 870 & 450 & 957 \\
Bilangan Tanggungan & - & 220 & 575 \\
Kadar kematian (per 1,000) & 232 & 3 & 1.1 \\
\hline
\end{tabular}

Sumber: Manderson, Sickness and the State, hlm. 146.

Kejayaan penyelidikan IMR di NNMB berdasarkan penyakit beri-beri, disenteri dan malaria, boleh dilihat melalui statistik berikut:

a. Penyakit Beri-Beri

\begin{tabular}{|c|c|c|}
\hline 1896 & $\begin{array}{l}\text { Kes dirawat } \\
\text { Kes kematian } \\
\text { Peratus kematian }\end{array}$ & $\begin{array}{l}11,953 \text { orang } \\
1,763 \text { orang } \\
14.8 \%\end{array}$ \\
\hline 1914 & $\begin{array}{l}\text { Kes dirawat } \\
\text { Kes Kematian } \\
\text { Peratus kematian }\end{array}$ & $\begin{array}{l}6,240 \text { orang } \\
686 \text { orang } \\
11.0 \%\end{array}$ \\
\hline
\end{tabular}

Sumber: Disesuaikan daripada FMSAR 1908, hlm. 28; FMSAR 1909, hlm. 27; FMSAR 1912, hlm. 32 dan FMSAR 1913, hlm. 29.

Nota: Data setiap tahun kecuali tahun 1908, 1909, 1912 dan 1913 berdasarkan data dari setiap negeri dalam Persekutuan.

b. Penyakit Disenteri

$\begin{array}{lll}1896 & \text { Kes dirawat } & 3,151 \text { orang } \\ & \text { Kes kematian } & 1,037 \text { orang } \\ 1914 & \text { Peratus kematian } & 32.9 \% \\ & \text { Kes dirawat } & 5,982 \text { orang } \\ & \text { Kes kematian } & 1,356 \text { orang } \\ & \text { Peratus kematian } & 23.9 \%\end{array}$

* Berlaku penurunan sebanyak 9.0 peratus

Sumber: Disesuaikan daripada Laporan Tahunan dan Laporan Perubatan Perak, Selangor, Negeri Sembilan dan Pahang, 1900 dan 1914: PKAR 1900, hlm. 50; PKAR 1914, hlm. xv; SAR 1901, hlm. xxv; SAR 1914, hlm. xvii; NSAR 1900, hlm. xvi; NSAR 1914, hlm. 18; PHGAR 1900, hlm. xii; dan PHGAR 1914, hlm. 26.

Nota: Selain dari tahun 1896 dan 1897 tidak termasuk data bagi negeri Pahang.

c. Penyakit Malaria

$\begin{array}{lll}1896 & \text { Kes dirawat } & 6,108 \text { orang } \\ & \text { Kes kematian } & 405 \text { orang } \\ & \text { Peratus kematian } & 6.6 \%\end{array}$


1914

$\begin{array}{ll}\text { Kes dirawat } & 29,727 \text { orang } \\ \text { Kes kematian } & 1,713 \text { orang } \\ \text { Peratus kematian } & 6.0 \%\end{array}$

* Berlaku penurunan sebanyak 0.6 peratus

Sumber: Disesuaikan daripada FMSAR 1908, hlm. 27; FMSAR 1909, hlm. 27; FMSAR 1910, hlm. 2, dalam SFMSGG 1911; FMSMR 1911, hlm. 3, dalam SFMSGG 1912 dan FMSMR 1914, hlm. 2, dalam SFMSGG 1915.

Nota: Data selain dari tahun 1908-1910 dan 1914 adalah berdasarkan data dari setiap negeri dalam persekutuan.

Berdasarkan statistik di atas, jika dibuat perbandingan antara tahun 1896 hingga 1914, maka peratus kematian pesakit beri-beri ialah 14.8 peratus sebelum menurun kepada 11.0 peratus (berlaku penurunan sebanyak 3.8 peratus). Statistik kematian pesakit disenteri pada tahun 1896 ialah 32.9 peratus sebelum menurun kepada 23.9 peratus pada 1914 (berlaku penurunan sebanyak 9.0 peratus). Manakala statistik kematian pesakit malaria pada tahun 1896 ialah 6.6 peratus sebelum menurun kepada tahun 1914 menjadi hanya 6.0 peratus (berlaku penurunan sebanyak 0.6 peratus). Penurunan statistik kematian pesakit beri-beri, disenteri dan malaria kemungkinan besar disumbangkan oleh penyelidikan IMR.

Penurunan kadar kematian bagi penyakit malaria terutama dalam kalangan buruh estet juga dapat dilihat antara tahun 1946 hingga 1959. Faktor penurunan ini berkait rapat dengan penghasilan ubat kuinin yang digunakan untuk penyakit ini sangat berkesan:89

The effect of Anti-Malaria measure at Kuala Lumpur is shown by a comparison of the death rate for 1947 with those for 1041 when the sork had virtually been completed. In 1947 the true total death rate for per 1000 was 35\% and the malaria death rate per 1000 was, in 1955 the rate was 74 and $4.9 \% .{ }^{90}$

Berdasarkan kenyataan di atas, membuktikan kejayaan yang telah dicapai hasil penyelidikan yang dijalankan oleh IMR. Pengurangan bilangan penghidap dan kadar kematian boleh dijadikan indeks keberkesanan dasar yang telah diperkenalkan oleh pemerintah British.

Kadar kelahiran dan kematian di Tanah Melayu juga dapat membuktikan peningkatan taraf kesihatan di Tanah Melayu. Hal ini dapat dilihat dalam jadual di bawah.

Jadual 10: Kadar Kelahiran dan Kematian di Tanah Melayu, 1911-1940

\begin{tabular}{|c|c|c|c|}
\hline Tahun & Penduduk ('000), 1891-1940 & Kadar Kelahiran Kasar (\%) & Kadar Kematian Kasar (\%) \\
\hline 1891 & $746.3^{\mathrm{a}}$ & & \\
1901 & $1,022.3^{\mathrm{a}}$ & 19.4 & 39.1 \\
1911 & $2,342.2^{\mathrm{c}}$ & 23.5 & 37.8 \\
1912 & -* $^{*}$ & 23.1 & 34.0 \\
1913 & - & 24.6 & 34.3 \\
1914 & - & 25.3 & 28.9 \\
1915 & - & 24.2 & 30.6 \\
1916 & - & 29.9 & 34.2 \\
1917 & - & 25.8 & 52.9 \\
1918 & - & 24.6 & 29.4 \\
1919 & - & 27.1 & 32.3 \\
1920 & - & & \\
\hline
\end{tabular}




\begin{tabular}{|l|c|c|c|}
\hline 1921 & $2,910.2^{\mathrm{c}}$ & 27.2 & 28.5 \\
1922 & - & 25.5 & 25.6 \\
1923 & - & 25.3 & 24.1 \\
1924 & - & 27.3 & 23.2 \\
1925 & - & 28.1 & 22.9 \\
1926 & - & 30.5 & \\
1927 & - & 32.5 & 30.7 \\
1928 & - & 32.4 & 28.0 \\
1929 & - & 36.5 & 24.6 \\
1930 & - & 33.3 & 24.1 \\
1931 & $3,788.5^{\mathrm{c}}$ & 34.0 & 19.1 \\
1932 & $1,622.9^{\mathrm{d}}$ & 35.5 & 18.5 \\
1933 & - & 35.4 & 20.2 \\
1934 & - & 35.9 & 21.4 \\
1935 & $1,777.4^{\mathrm{d}}$ & 38.7 & 19,9 \\
1936 & - & 37.8 & 19.2 \\
1937 & $1,961.4^{\mathrm{d}}$ & 39.7 & 19.9 \\
1938 & $2,089.8^{\mathrm{d}}$ & 41.0 & 19.1 \\
1939 & $2,123.3^{\mathrm{d}}$ & 39.7 & 17.5 \\
1940 & $2,169.3^{\mathrm{d} 91}$ & & 18.6 \\
\hline
\end{tabular}

* Data Tidak Lengkap

Sumber: 1. 1891 dan 1901: Kertas Penyelidikan Bil. 10, Penduduk Malaysia, hlm. 9.

2. 1901, 1921, 1931 \& 1947: Laporan Banci Penduduk 1947, Malaya, hlm. 584-587 dan hlm. 132.

3. 1932, 1935, 1937-1940: Laporan Pendaftaran Besar Kelahiran dan Kematian atau Siri Masa Perangkaan Penting Semenanjung Malaysia, 1911-1985.

4. 1941: Laporan Pendaftaran Kelahiran dan Kematian 1947.92

Berdasarkan jadual di atas, jelas berlaku peningkatan taraf kesihatan di Tanah Melayu berdasarkan kadar kematian yang menunjukkan penurunan dan kadar kelahiran yang menunjukkan peningkatan. Jika dibuat perbandingan antara tahun 1911 dengan tahun 1939, dalam tahun 1911 kadar kelahiran kasar adalah hanya 19.4\% berbanding dengan $41.0 \%$ pada tahun 1939. Kadar peningkatan kelahiran adalah sebanyak 21.6\%. Untuk jangka masa yang sama, kadar kematian penduduk pula menurun dengan ketara. Pada tahun 1911, kadar kematian penduduk TM adalah 39.1\% sebelum menurun menjadi 17.5\%. Pada tahun 1939, kadar penurunan sebanyak $21.6 \%$. Kadar kelahiran tinggi dan kadar kematian rendah sudah pasti dipengaruhi oleh taraf kesihatan yang baik, prasarana kesihatan cukup dan sistem perubatan cekap. Peningkatan taraf kesihatan ini sudah pasti hasil sumbangan penyelidikan yang telah dilakukan oleh IMR. Jadi jelas bahawa keputusan kerajaan menubuhkan IMR pada tahun 1900 telah berjaya membantu British untuk menangani masalah penyakit yang dihadapi oleh penduduk Tanah Melayu, termasuk para buruh imigran di NNMB.

\section{Kesimpulan}

Institut Penyelidikan Perubatan atau Institute of Medical Research (IMR), Kuala Lumpur merupakan sebuah pusat penyelidikan perubatan yang penting pada abad ke-19. Penubuhan IMR dalam tahun 1900 adalah sesuatu yang relevan kerana pada ketika itu, beberapa wabak penyakit seperti beri-beri, disenteri dan malaria yang telah melanda menyebabkan ramai orang-orang tempatan telah menjadi korban terhadap wabak penyakit ini. Ini menimbulkan masalah besar kepada British dan menghalang matlamat British untuk meneroka ekonomi Tanah Melayu. Sebagai contoh, pelabuhan Port Swettenham telah diarahkan tutup pada November 1901 oleh Persuruhjaya Tinggi British, Frank Swettenham selepas hanya dua bulan beroperasi akibat serangan penyakit malaria. Hampir semua staf 
dan pekerja yang bekerja di pelabuhan tersebut telah dijangkiti malaria. Penutupan Port Swettenham adalah satu daripada puluhan kes yang berlaku di Tanah Melayu yang disebabkan oleh serangan penyakit seperti malaria dan beri-beri. Atas kesedaran ini, keperluan kepada satu institut penyelidikan di Tanah Melayu pada ketika itu adalah sangat tepat pada masanya untuk menjalankan penyelidikan penyakit tropika. Penubuhan institut ini sememangnya telah menyelesaikan masalah sosioekonomi British ketika itu.

\section{Nota}

1 The Institute of Medical Research 1900-1950, hlm. 40.

2 Malay Mail, 26 Julai 1902, hlm. 3.

3 Noraini Mohamed Hassan, Penyakit Tropika di Negeri-negeri Melayu Bersekutu 1896-1914, Kuala Lumpur: Penerbit Universiti Malaya, 2008, hlm. 21.

4 High Commissioner's Despatch File, Federated Malay State, 156/1899.

5 Menurut Malay Mail, idea asal penubuhan institut ini datang daripada Dr. Braddon dan Dr. H.A. Haviland. Perkara tersebut kemudiannya diajukan kepada Sir Michael Foster dan Dr. Manson yang bertindak sebagai jawatankuasa penimbang sebelum memutuskan pengambilan Dr. Hamilton Wright sebagai pengarah pertama. Lihat Malay Mail, 26 Julai 1902, hlm. 3.

6 Annual Report of I.M.R for the year 1902, hlm. 3.

$7 \quad 70$ Tahun (1900-1970) Penyelidikan Perubatan Di Pusat Penyelidikan Perubatan, Kuala Lumpur, 1971.

8 Ibid.

9 William B. Hennesey, Lay Cource in Tropical Medicene Second Edition, Canberra: Australian Government Publishing Services, 1976, hlm. 3-4.

10 Barbara Watson Andaya dan Leonard Y. Andaya, Sejarah Malaysia, Kuala Lumpur: MacMillan. 1983, hlm. 243.

11 Chan Chai Hon, The Development of British Malaya 1896-1909, Kuala Lumpur: Oxford University Press, 1967, hlm. 49.

12 Loh Fok Seng, The Malay State 1877-1895: Political Change and Sosial Policy, Singapore: Oxford University Press, 1969, hlm. 52.

13 Pada akhir tahun 1911, terdapat 1,998 batu jalan bertar di NNMB dan 1,542 batu jalan tidak bertar. Menjelang tahun 1928, jalan raya sudah menghubungkan Perlis dengan Johor Bahru. Perkembangan bijih timah menggalakkan pembinaan jalan kereta api. Jalan kereta api pertama yang diusahakan oleh British diperkenalkan di Larut. Kerja-kerja pembinaan bermula pada 1882 untuk menghubungkan Taiping dengan Kuala Sepetang (Port Weld). Kerja-kerja hanya siap pada Jun 1885. Selangor membina jalan kereta api menghubungkan Kuala Lumpur dengan Pelabuhan Klang pada Jun 1886. Negeri Sembilan pula membina jalan kereta api menghubungkan Seremban dengan Port Dickson pada tahun 1891. Menjelang tahun 1931, rangkaian sistem jalan kereta api Tanah Melayu sudah terbentuk. Pembinaannya jelas membantu perkembangan ekonomi.

14 Zainal Abidin Abdul Wahid, Glimpses of Malaysian History, Kuala Lumpur: Dewan Bahasa dan Pustaka, 1970, hlm. 109.

15 Bathemavathi A/P Khatavarayen, 'Sejarah Perkembangan Institut Penyelidikan Perubatan, 19461959', Latihan Ilmiah B.A., Jabatan Sejarah, Universiti Malaya, hlm. 9.

16 Serangan penyakit beri-beri terhadap komuniti lombong di Perak dalam tempoh 1904 hingga 1906 contohnya, angka kematian setiap batu yang dicatatkan adalah 7,514 orang, 7,089 orang dan 7,532 orang mengikut tahun. Di Selangor, pada tahun 1910, jumlah pesakit Cina yang dirawat berbanding dengan jumlah keseluruhan adalah 12,914 orang daripada 25,082 orang, manakala pada tahun 1911, pesakit Cina berjumlah 16,429 orang daripada 31,637 orang. Di Negeri Sembilan, pada tahun 1912, jumlah pesakit Cina adalah 9,787 orang berbanding dengan 6,425 orang (pesakit India), 954 (pesakit Melayu dan Jawa). Di Pahang pada tahun 1900, 360 daripada 365 pesakit dirawat Hospital Cina Bentong adalah pesakit berbangsa Cina.

17 Ibid.

18 F.A. Swettenham, 'British Rule in Malaya', dalam Paul H. Kratoska (ed.), Honourable Intentions Talk on the British Empire in South-East Asia Delivered at the Royal Colonial Institute 1974-1928, Singapore: Oxford University Press, 1983, hlm. 186. 
Sila teliti Hairudin Harun, 'Medicine and Imperialism: A study of the British Colonial Medical Establishment, Health Policy and Medical Research in The Malaya Peninsula, 1786-1918', Tesis $\mathrm{PhD}$, University College London, 1988; Julia Meredith Raja Segaran, 'Development of the Medical Services in the Malay States, 1881-1911: From Death Houses to Hospitals', Disertasi M.A., Jabatan Sejarah, Universiti Malaya, 1982.

http://www.hids.arkib.gov.my/print.php?type=A\&item_id=1120.

Ibid.

http://www.imr.gov.my/ISO/manual/Manual Kualiti.doc.

Ibid.

Dr. Hamilton Wright (1900-1903) adalah Pengarah IMR pertama dan salah seorang pengasas IMR. Beliau dilahirkan di Clevend Ohio, Amerika Syarikat pada tahun 1867 dan meninggal dunia pada bulan Januari 1917. Beliau mendapat ijazah kelas pertama dalam bidang perubatan daripada Universiti McGill, Montreal, Kanada pada tahun 1895. Beliau kemudian ditawarkan Biasiswa John Lucas Walker untuk mengkaji neuropatologi di Universiti Cambridge sebelum ditawarkan bekerja sebagai Patologis di London School of Tropical Medecine. Beliau Banyak memberi tumpuan kepada penyelidikan ke atas penyakit beri-beri dan malaria. Beliau pernah membuat kajian ke atas Penjara Kuala Lumpur bagi mengenal pasti parasit malaria yang pertama di Tanah Melayu. Beliau telah menjalankan kajian sistematik bagi mengenal pasti punca penularan penyakit malaria selain pernah menerbitkan dua buku iaitu The Malaria Fevers of British Malaya (1901), dan buku An Enquiry into the Etiology and Pathology of Beri-Beri (1902).

Dr. Charles Wilberforce Daniels dilahirkan pada tahun 1862 dan menerima pendidikan dari Manchester Grammar School, Trinity College, Cambridge dan London Hospital. Beliau mengambil alih jawatan Pengarah IMR daripada Dr. Wright pada tahun 1903. Beliau memegang jawatan tersebut selama 6 tahun sebelum dilantik menggantikan Dr. Manson sebagai Penasihat Perubatan untuk Tanah Jajahan pada tahun 1912.

Dr. Henry Fraser menggantikan Dr. Daniels sebagai Pengarah IMR pada tahun 1906. Dr. Henry Fraser (1906-1916) dilahirkan pada 13 Januari 1873. Beliau telah dilantik sebagai Pengarah IMR pada 30 Mac 1906 tetapi hanya memulakan tugasnya secara rasmi pada 3 Mei tahun yang sama. Lihat Federated Malay States Civil Service List, March 1911, hlm. 106. Beliau terlatih dalam bidang patologi, kimia dan farmakologi dan pernah dianugerahkan Anderson Research Scholarship. Beliau membuktikan beri-beri adalah penyakit kekurangan nutrien makanan. Dengan bantuan A. Stanton, W.G. Brandon dan Fletcher, beliau berjaya menunjukkan bahawa beras putih menyebabkan beri-beri tetapi beras India yang telah dirawat tidak menyebabkan penyakit tersebut. Lihat ibid., hlm. 317-318.

Ibid., hlm. 372.

Noraini Mohamed Hassan, Penyakit Tropika di Negeri-negeri Melayu Bersekutu, hlm. 21.

FMSAR 1899, hlm. 6.

http://www.imr.gov.my/index.php/my/corporate-info-2/sejarah.

Noraini Mohamed Hassan, Penyakit Tropika di Negeri-negeri Melayu Bersekutu, hlm. 31.

Lihat contohnya surat-menyurat dalam CO273/98/7160; CO273/103/7811 dan CO273/116/19632. Hanya pada tahun 1883, penjara di Singapura berjaya dipulihkan daripada ancaman beri-beri. Lihat CO273/119; CO273/120 dan CO273/127.

Hugh Low, Residen Perak kepada Setiausaha Kolonial Negeri-negeri Selat bertarikh 1 Julai 1881, CO273/109/14738.

Ho Tak Ming, Doctors Extraordinaire, Perak: Ho Tak Ming, 2000, hlm. 171.

Dr. Ambrose Thomas Stanton (1916-1926) dilahirkan pada tahun 1875 di Ottawa, Kanada. Beliau menamatkan pengajian pada tahun 1899 di Kolej Trinity, Toronto sebelum memasuki Institute as Bacterialogist pada tahun 1907. Beliau telah banyak membantu Pengarah Sekolah Perubatan Penyakit Tropikal dalam mengkaji penyakit beri-beri. Beliau tiba di Kuala Lumpur pada tahun 1907. Beliau telah melakukan penyelidikan penyakit beri-beri di ladang Durian Tipus yang telah dibuka oleh Dr. Fraser iaitu Pengarah IMR ketiga (Dr. Stanton menghabiskan masa selama setahun di ladang tersebut dengan tinggal di sebuah pondok hanya untuk melakukan penyelidikan dan kajian ke atas penyakit beri-beri). Beliau sangat sinonim dengan penyakit beriberi sehingga menjadi bualan dalam kalangan buruh India yang mengatakan bahawa sebut 
sahaja beri-beri, mereka pasti mengingati Dr. Stanton. Beliau juga telah diberi tanggungjawab untuk mereka bentuk makmal di blok selatan IMR.

C.P. Lucas kepada John Anderson bertarikh 12 Mac 1908, CO,273/331/42737

"Report from the Institute for Mendical Research for the Period from April $1^{\text {st }}$ to September $30^{\text {th }}$ $1909^{\prime \prime}, \mathrm{CO}, 273 / 331 / 38552$.

W.L. Braddon kepada Pemangku Setiausaha Residen Negeri Sembilan bertarikh 16 Jun 1908, CO, 273/341/32624.

Dr. William Fletcher (1926-1927) mendapat pendidikan di Caius College, Cambridge dan juga St. Mary's Hospital, Paddington. Beliau banyak membantu Dr. Fraser dan Dr. Stanton dalam melakukan penyelidikan ke atas Durian Tipus Beri-Beri. Dalam kajian beliau, lebih seribu kes telah diperhatikan dan kesimpulannya adalah Biillari Disenteri adalah jauh lebih penting daripada amoeba. Sesetengah daripada kes telah dibuktikan bahawa Basillari menunjukkan kadar kematian yang lebih tinggi. Beliau bertanggungjawab memisahkan demam tipus sebagai salah satu demam di Tanah Melayu. Penemuan ini sangat memberi impak besar terhadap penyelidikan Tipus.

The Institute for Medical Research 1900-1950, hlm. 107.

"Report from the Institute for Medical Research for the Period from April $1^{\text {st }}$ to September $30^{\text {th }}$ $1909^{\prime \prime}, \mathrm{CO}, 273 / 351 / 38552$.

John Anderson Kepada Earl of Crewe bertarikh 29 Mac 1910, CO,273/360/12035.

A.T. Stanton, Pemangku Pengarah Institut Penyelidikan Perubatan kepada Pegawai Perubatan Kanan Negeri-negeri Melayu Bersekutu bertarikh 14 Julai 1911, CO,273/374/30328.

Malay Mail, 14 April 1910, hlm. 5.

Malay Mail, 17 September 1912, hlm. 7.

Sungguhpun demikian, eksperimen tetap diteruskan untuk memastikan bahan yang terkandung dalam lapisan subpericarpal beras yang diuji. Lihat "Report from the institute for Medical Research for the Period from April $1^{\text {st }}$ to September $30^{\text {th }} 1910^{\prime \prime}, C O, 273 / 385 / 4119$ dan CO,273/388.

Malay Mail, 29 November 1913, hlm. 7.

SAR 1907, hlm. 21; NSAR 1910, hlm. 10.

Noraini Mohamed Hassan, Penyakit Tropika di Negeri-negeri Melayu Bersekutu, hlm. 63.

Ibid.

Ibid.

FMSAR 1902, hlm. 22

FMSAR 1909, hlm. 28.

FMSAR 1903, hlm. 35.

FMSAR 1910, hlm. 7.

Pada tahun 1910, Dr. Freer telah menjalankan penyelidikan tentang spesis nyamuk tiruk di Penjara Pudu, Kuala Lumpur. Sekumpulan banduan yang telah dilatih untuk menangkap nyamuk dipertanggungjawabkan untuk melakukan kerja-kerja penangkapan pada setiap hari. Berdasarkan jumlah penangkapan dan rekod hujan, Dr. Freer menyimpulkan bahawa jumlah paling banyak ditangkap adalah pada penghujung tahun 1910 apabila berlakunya penularan malaria yang ketara. Spesis nyamuk tiruk yang Bbrjaya dikenalpasti oleh Dr. Stanton adalah myzomyia rossii, myzorhyncus barbirostris, nyssorhyuncus willmori, cellia kochii dan nyssorhyuncus nivipes. Lihat ibid., hlm. 4.

Ibid. Spesis yang membiak di air kotor adalah seperti myzomyia rossii dan cellia kochii dan nyssorhyuncus nivipes, manakala nyssorhyncus willmori membiak dalam air yang bersih.

FMSAR 1911, hlm. 14-15.

Parasit tertian malignan berkembang di dalam myzomyia albirostris, nyssorhynchus fuliginosus dan nyssorhynchus maculates, manakala nyssomyzomyia rossii, myzorhynchus barbirostris, myzorhynchus sinensis dan patagiamyia umbrosus menghasilkan keputusan yang negatif. Eksperimen berikutnya menggunakan spesis nyamuk yang ditangkap iaitu myzomyia albirostris, nyssorhynchus maculates dan myzorhynchus sinensis menunjukkan kehadiran zigot parasit malaria.

Ibid., hlm. 15.

FMSMR 1912, hlm. 39.

FMSAR 1913, hlm. 24.

Bersama dengan Major S.P. James dari Perkhidmatan Perubatan India, beliau melakukan perbandingan sepsis nyamuk tiruk Tanah Melayu dengan India. Beliau juga mengkaji koleksi 
nyamuk yang diawet di British Museum of Natural History, London dan menjalinkan hubungan yang baik dengan Lt. Kol. A. Alcock, Ketua Jabatan Etimologi, London School of Tropical Medicine; E.E. Austen dan F.W. Edwards dari British Museum. Lihat FMSAR 1912, hlm. 39. b: NNS (Melaka dan Pulau Pinang).

c: Data banci penduduk untuk Semenanjung Malaysia.

d: Anggaran penduduk pertengahan tahun dan terdiri daripada NNMB. Angka tahun 1911, 1921 dan 1931 termasuk kalangan penduduk sementara.

92 Anggaran penduduk bagi tahun 1891 dan 1901 merujuk kepada NNMB (Perak, Pahang, Selangor, Negeri Sembilan) dan Negeri-negeri Selat (Melaka dan Pulau Pinang). Anggaran penduduk bagi tempoh 1911-1962 pula merujuk kepada Semenanjung Tanah Melayu sahaja. 